\title{
ALAT PERMAINAN EDUKATIF (APE) BERBASIS BAHAN LINGKUNGAN DALAM MENGATASI PERMASALAHAN PEMBELAJARAN PENDIDIKAN ANAK USIA DINI
}

http://kolokium.ppj.unp.ac.id/

Jurusan Pendidikan Luar Sekolah

Fakultas Ilmu Pendidikan

Universitas Negeri Padang

Sumatera Barat, Indonesia

Volume 6, Nomor 2, Oktober 2018 DOI: $10.5281 /$ zenodo. 1471716

\author{
Solfema ${ }^{1,2}$, Syafruddin Wahid ${ }^{1}$, Alim Harun Pamungkas ${ }^{1}$ \\ ${ }^{1}$ Jurusan Pendidikan Luar Sekolah Fakultas Ilmu Pendidikan Universitas Negeri Padang \\ 2Email: solfema@fip.unp.ac.id
}

\begin{abstract}
Education is important for the progress of the nation. Education must be done in a person's life, including for early childhood. The problem is that there are still many early childhood education providers that have not met the expected quality standards. One of the reasons is that there are still limited Educative Game Tools (APE) used by education in the implementation of learning. Many educators claim that it is difficult to get an Educational Game Tool (APE). This problem solving can be done through various trainings, training, training, and the creation of environmental-based Educative Game Tools (APE) needs to be carried out. Training methods are carried out in the form of presentations of theories and practical exercises. The results of the training show that with training activities it was found that the insights and skills of PAUD educators in the procurement and manufacture of Educational Game Tools (APE) based on environmental materials.
\end{abstract}

Keywords: Educational Game Tools (APE), Early Childhood Education (PAUD)

\section{PENDAHULUAN}

Pendidikan merupakan aset penting bagi kemajuan sebuah bangsa. Pendidikan nasional mempunyai fungsi umum, ialah ke arah terbentuknya kepribadian nasional dari peserta didik yang konkret dan utuh (Tilaar, 2001). Pendidikan merupakan suatu kemutlakan dalam kehidupan seseorang, termasuk bagi anak usia dini (Seefeld, Carol \& Barbour, 1986). Masa usia dini adalah masa yang paling penting sepanjang usia hidupnya. Hal ini dikarenakan masa usia dini adalah masa pembentukan fondasi dan masa pembentukan kepribadian yang akan menentukan pengalaman anak selanjutnya sehingga dikatakan bahwa masa kanak-kanak merupakan gambaran awal manusia sebagai seorang manusia (Hurlock, 1978). Sedemikian pentingnya usia dini, maka pembelajaran di usia dini tidak mungkin diselenggarakan seadanya, namun membutuhkan usaha yang terencana secara sistematis, hal ini sesuai dengan tujuan program pembelajaran yakni untuk membentuk, meletakkan dasar ke arah perkembangan sikap pengetahuan, keterampilan, dan kreativitas yang diperlukan anak untuk dapat menyesuaikan diri dengan lingkungannya dan untuk mempersiapkan pertumbuhan dan perkembangan ke tahap selanjutnya. 
Arikunto (1993) mengemukakan bahwa pembelajaran adalah bantuan pendidikan kepada anak didik agar mencapai kedewasaan di bidang pengetahuan, keterampilan, dan sikap. Kegiatan bermain menjadi perhatian besar dalam pendidikan anak usia dini. Para ahli pendidikan anak usia dini memandang bahwa bermain merupakan faktor penting dalam kegiatan pembelajaran anak usia dini (Matakupan, 1993). Masa anak usia dini salah satunya dikenal sebagai masa bermain. Bagi anak bermain memiliki fungsi dan manfaat yang sangat penting. Bermain bukan hanya sekedar menjadi kesenangan, melainkan adalah suatu kebutuhan yang harus dipenuhi (Vygotsky, 2016). Hampir sebagian besar waktu anak digunakan untuk bermain, karena dengan bermain itulah anak usia dini tumbuh dan mengembangkan seluruh aspek perkembangan yang ada pada dirinya. Musfiroh (2005) mengemukakan bahwa dengan bermain memungkinkan anak untuk mengeksplorasikan dunianya, mengembangkan pemahaman sosial dan kultural, membantu anak-anak mengekspresikan apa yang mereka rasakan dan mereka pikirkan, memberikan kesempatan bagi anak untuk menemukan dan menyelesaikan masalah, serta mengembangkan bahasa dan keterampilan atau konsep beraksara. Selanjutnya Catron, Carol E. \& Allen (1999) menjelaskan bahwa bermain memiliki kekuatan untuk menggerakkan perkembangan anak. Sedangkan Hoorn (1999) menjelaskan bahwa pada masa anak-anak, bermain merupakan landasan bagi perkembangan mereka, karena bermain merupakan bagian dari perkembangan sekaligus memberi energi perkembangan itu sendiri.

Oleh sebab itu, perhatian terhadap penyelenggaraan Pendidikan Anak Usia Dini (PAUD) perlu mendapat perhatian yang serius. Permasalahannya adalah bahwa penyelenggaraan pendidikan anak usia dini masih banyak yang belum memenuhi standar mutu yang sesuai dengan yang diharapkan. Salah satu penyebabnya adalah bahwa masih terbatasnya Alat Permainan Edukatif (APE) yang digunakan oleh pendidikan dalam pelaksanaan pembelajaran. Beranjak dari konsep dan pentingnya bermain yang telah dibahas pada di atas. Dalam bermain, dari segi pendidikan adalah kegiatan permainan menggunakan alat permainan yang mendidik serta alat yang bisa merangsang perkembangan aspek kognitif, sosial, emosi, dan fisik yang dimiliki anak (Mayke, 2001). Oleh karena itu, dari sudut pandang pendidikan bermain sangat membutuhkan alat permainan yang mendidik. Alat permainan yang mendidik inilah yang kita sebut dengan alat permainan edukatif (APE). Banyak pendidik yang menyatakan sulitnya untuk mendapatkan alat permainan edukatif (APE). Padahal alat permainan edukatif itu sangat banyak dan mudah didapatkan di lingkungan belajar anak. Adams (1975) berpendapat bahwa permainan edukatif adalah semua bentuk permainan yang dirancang untuk memberikan pengalaman pendidikan atau pengalaman belajar kepada para pemainnya, termasuk permainan tradisional dan modern yang diberi muatan pendidikan dan pengajaran. Oleh sebab itu, di daerah pedesaan maka alat permainan edukatif yang bersifat tradisional dan pemanfaatan bahan lingkungan sangat mudah didapatkan. Hal ini oleh pendidik belum dimanfaatkan, karena masih terbatasnya wawasan dan keterampilan para pendidik tenaga kependidikan anak usia dini.

Sehubungan dengan permasalah dalam upaya pengembangan dan penggunaan alat permainan edukatif (APE) pada PAUD di Kenagarian Lubuk Jantan, Kecamatan Lintau Buo Utara, Kabupaten Tanah Datar diperlukan beberapa usaha di antaranya adalah peningkatan pengetahuan para pendidik PAUD tentang konsep, prinsip, dan jenis atau bentuk alat permainan edukatif untuk pendidikan anak usia dini, dan selanjutnya melatihkan keterampilan membuat dan menggunakan alat permainan edukatif (APE) dengan memanfaatkan bahan bahan yang ada di lingkungan daerah setempat. Untuk itu perlu 
Alat Permainan Edukatif (APE) Berbasis Bahan Lingkungan...

diselenggarakan pelatihan pengembangan dan penggunaan alat permainan edukatif (APE) berbasil bahan lingkungan.

\section{METODE}

Mengacu pada rumusan permasalahan, maka pelatihan pengembangan dan penggunaan alat permainan edukatif (APE) dilakakukan dua bentuk kegiatan, yakni kegiatan pemberian teori-teori yang berkaitan dengan alat permainan edukatif (APE), selanjutnya diberikan beberapa keterampilan membuat dan menggunakan alat permainan edukatif untuk pendidikan anak usia dini. Kegiatan yang bersifat teoritis diperlukan agar para peserta dapat memahami konsep alat permainan edukatif, serta memahami manfaat atau kegunaan alat permainan edukatif (APE) dalam mengembangkan berbagai aspek kecerdasan anak usia dini yang meliputi aspek kognitif, sosial, emosi, bahasa, seni dan naturalistik. Selanjutnya, peserta dapat mempertimbangkan berbagai bahan lingkungan yang ada di daerah mereka yang dapat dijadikan bahan untuk pembuatan alat permainan edukatif (APE). Kegiantan yang bersifat teoritis mencakup hal-hal sebagai berikut (1) Penyajian materi tentang konsep pembelajaran anak usia dini, alat permainan edukatif (APE) dalam pembelajaran anak usia dini, konsep dan prinsip alat permainan edukatif (APE), serta mengenal berbagai alat permainan edukatif (APE) yang berbasis bahan lingkungan sekitar.; (2) Diskusi kelompok guna pemantapan tentang materi yang disampaikan oleh pemateri, sekaligus mengidentifikasi berbagai bahan yang ada di lingkungan sekitar yang dapat dijadikan alat permainan edukatif (APE). Kegiatan yang bersifat praktik keterampilan diberikan dengan tujuan agar peserta tidak hanya mengerti secara teoritis saja namun harus punya keterampilan untuk membuat alat permainan edukatif. Sebab berapa pun kayanya secara teoritis namun jika belum terampil untuk pembuatannya maka teori tersebut tidak akan membawa makna dalam yang signifikan dalam memecahkan permasalahan keterbatasan alat permainan edukatif (APE). Kegiatan yang bersifat praktik keterampilan adalah sebagai berikut. (1) Narasumber mendemonstrasikan alat permainan edukatif (APE) yang berbasis bahan lingkungan sekitar; (2) Peserta mempraktikkan keterampilan yang dilatihkan dalam kelompok-kelompok kecil yang dibimbing oleh narasumber bersama dengan para pendamping kegiatan; (3) Membimbing para peserta dalam penggunaan alat permainan edukatif (APE) yang berbasis bahan lingkungan sekitar berdasarkan keterampilan yang diperoleh.

\section{PEMBAHASAN}

Berdasarkan hasil pemantauan dan evaluasi yang dilakukan baik selama kegiatan yang bersifat penyajian materi dalam bentuk teoritis maupun kegiatan yang bersifat praktik keterampilan kegiatan pelatihan pengembangan dan penggunaan alat permainan edukatif (APE) pad PAUD di Kenagarian Lubuk Jantan, Kecamatan Lintau Buo Utara, Kabupaten Tanah Datar dapat diperoleh hasil sebagai berikut.

\section{Peningkatan Pengetahuan dan Wawasan Peserta Pelatihan}

Dari hasil pengamatan selama kegiatan belajar dan dilakukan evaluasi secara lisan terhadap peserta latihan, sebagian besar peserta telah menunjukkan peningkatan pengetahuan dan perubahan sikap secara signifikan tentang alat permainan edukatif (APE) yang berbasis bahan lingkungan sekitar. Diperolehnya peningkatan pengetahuan dan perubahan sikap 
secara signifikan amat erat kaitannya dengan kesesuaian materi yang diberikan dengan kebutuhan peserta pelatihan. Di samping itu, diikuti dengan menariknya teknik penyajian para narasumber yang didukung oleh media dan contoh yang menarik pula, yang menyebabkan semua peserta antusias dan konsentrasi selama mengikuti pelatihan. Dalam setiap penyajian materi oleh narasumber, narasumber memberikan kesadaran kepada peserta agar arif dalam memanfaat bahan lingkungan sebagai alat permainan edukatif (APE) dalam menunjang pembelajaran bagi anak usia dini.

\section{Praktik Pengadaan dan Pembuatan Alat Permainan Edukatif (APE) yang Berbasis Lingkungan Sekitar}

Setelah memperoleh wawasan tentang teori-teori tentang pendidikan anak usia dini dan alat permainan edukatif, maka selanjutnya diberikan keterampilan mengadakan dan membuat alat permainan edukatif yang berbasis bahan lingkungan yang dapat dijadikan sarana dalam pembelajaran, yang pada akhirnya dapat mengatasi kesulitan pendidik dan alat permainan edukatif (APE) dalam proses pendidikan bagi anak usia dini. Kegiatan dimulai dengan pemberian pengarahan dan pendemonstrasian pembuatan dan hasil yang telah diperoleh narasumber. Selanjutnya, diteruskan dengan praktik langsung oleh semua peserta yang dibimbing oleh narasumber. Hasil kerja masing masing peserta dievaluasi dan diberikan masukan secara langsung oleh narasumber. Peserta diberikan kesempatan untuk berdialog dan mendiskusikan ide-ide dan kesulitan-kesulitan masing-masing. Selama kegiatan, mereka sangat antusias mengikuti kegiatan pelatihan yang diberikan oleh narasumber. Dari hasil praktik, semua alat permainan edukatif (APE) yang dihasilkan memperoleh hasil yang memuaskan. Para peserta sudah dapat membuat dan mengadakan sendiri alat permainan edukatif (APE) untuk pembelajaran anak usia dini. Para peserta juga mencoba menghasilkan sendiri sesuai dengan kreativitas masing-masing.

\section{KESIMPULAN}

\section{Kesimpulan}

Berdasarkan penyelengggaraan program yang dilakukan, dapat diambil kesimpulan sebagai berikut.

1) Pelaksanaan program berjalan dengan efektif sesuai dengan rencana yang telah disusun. Semua peserta yang telah diidentifikasi dapat mengikuti program mulai dari awal kegiatan samai dengan kegiatan penutupan dan semua personalia yang bertugas telah menjalankan semua tugas dan tanggung jawab masing-masing. Selama penyelenggaraan kegiatan selalu didampingi oleh pimpinan daerah setempat beserta dengan pemuka masyarakatnya.

2) Peserta pelatihan telah memahami teori-teori tentang pembelajaran dan alat permainan edukatif yang sebagai dasar teori untuk praktik pengadaan dan pembuatan alat permainan edukatif dalam kegiatan pembelajaran di PAUD.

3) Peserta pelatihan telah trampil membuat dan mengadakan berbagai alat permainan edukatif (APE) dengan memanfaatkan bahan yang ada di lingkungan daerah setempat. Alat permainan edukatif (APE) ini ada yang dibuat dari bahan lembah rumah tangga dan ada yang dengan memanfaatkan bahan tanaman, dedaunan dan rempah rempah, serta berbagai jenis buah dan bunga-bungaan yang ada di lingkungan. 
Alat Permainan Edukatif (APE) Berbasis Bahan Lingkungan...

4) Peserta pelatihan sudah mampu menggunakan alat permainan edukatif (APE) dengan memanfaatkan bahan yang ada di lingkungan daerah setempat dalam proses pembelajaran di lembaga pendidikan anak usia dini.

\section{Saran}

Adapun saran yang bisa diberikan sebagai berikut

1) Kepada peserta disarankan agar kemampuan yang sudah dimiliki tetap bisa dikembangkan melalui usaha belajar mandiri dari berbagai sumber yang relevan, baik dari sumber cetak maupun online.

2) Sehubungan dengan tingginya minat masyarakat, disarankan kepada pemerintah setempat untuk melaksanakan kegiatan yang sejenis guna peningkatan keterampilan pendidik dan tenaga kependidikan PAUD dalam pengadaan alat permainan edukatif (APE)

3) Kepada tenaga pendidikan yang mempunyai perhatian khusus terhadap pendidikan anak usia dini diharapkan kesediaannya untuk berpartisipasi dalam meningkatkan kemampuan dan keterampilan tenaga pendidik dan kependidikan anak usia dini.

4) Pengelola pendidikan nonformal hendaknya memperbanyak kegiatan yang dapat membantu masyarakat dengan kegiatan yang serupa agar demi peningkatan pembangunan pendidikan anak usia dini (PAUD).

\section{DAFTAR RUJUKAN}

Adams, D. . (1975). Simulation Games: An Approach to Learning. Ohio: Jones Publishing Company.

Arikunto, S. (1993). Manajemen Pengajaran Secara Manusiawi. Jakarta: Rineka Cipta.

Catron, Carol E. \& Allen, J. (1999). Early Childhood Curriculum: A Creative-Play Model. New Jersey: Merill,Prentice-Hall.

Hoorn. (1999). Play at the Centre of the Curriculum. New Jersey: Merill, Prentice-Hall.

Hurlock, E. B. (1978). Child Development, Sixth Edition. New York: Mc. Graw Hill, Inc.

Matakupan. (1993). Teori Bermain. Jakarta: Depdikbud.

Mayke, S. T. (2001). Bermain, Mainan, dan Permainan untuk Pendidikan Usia Dini. Jakarta: Gramedia.

Musfiroh, T. (2005). Bermain Sambil Belajar dan Mengasah Kecerdasan. Jakarta: Depdiknas.

Seefeld, Carol \& Barbour, N. (1986). Early Childhood Education. New York: MacMillan.

Tilaar, H. A. . (2001). Manajemen Pendidikan Nasional: Kajian Pendidikan Masa Depan. Bandung: PT Remaja Rosdakarya.

Vygotsky, L. S. (2016). Play and its Role in the Mental Development of the Child. International Research in Early Childhood Education, 7(2), 3-25. 